\title{
Cycad biodiversity in the Bahamas Archipelago and conservation genetics of the threatened Zamia lucayana (Zamiaceae)
}

\author{
Michael Calonje, Alan W. Meerow, Lindy Knowles, David Knowles \\ M. Patrick Griffith, Kyoko Nakamura and Javier Francisco-Ortega
}

\begin{abstract}
A conservation assessment for the three cycad species native to the Bahamas Islands is presented. Results are based on field surveys on all islands where these species occur. Zamia angustifolia is native to Eleuthera, Zamia integrifolia is native to Abaco, Andros, Eleuthera, Grand Bahama and New Providence, and Zamia lucayana is endemic to Long Island. $Z$. angustifolia is of the highest conservation concern because of the small number of adult plants, its restricted distribution and the extensive development occurring within its habitat. Z. integrifolia also has a restricted distribution on Eleuthera and Grand Bahama and, although threatened by urban development in New Providence, it is relatively common on Abaco and Andros. Z. lucayana comprises three populations within a narrow strip of land of c. $1 \mathrm{~km}^{2}$; we propose a reassignment of its current conservation status from Endangered to Critically Endangered. We assessed the genetic structure of Z. lucayana based on 15 polymorphic microsatellite DNA loci; this indicated that the three known populations should be considered a single management unit. However, the high number of private alleles suggests that genetic drift, indicative of recent fragmentation, is progressing. We propose in situ conservation strategies, and we also collected germplasm from a total of 24 populations of these three cycad species, for ex situ conservation.
\end{abstract}

Keywords Biodiversity hotspot, Bahamas, Caribbean, conservation management, cycad, genetic structure, Red List, Zamia lucayana

Michael Calonje* and M. Patrick Griffith Montgomery Botanical Center, Coral Gables, Miami, USA

Alan MeErow and Kyoko NaKamura USDA-ARS-SHRS, National Germplasm Repository, Miami, USA

Lindy KNowles Bahamas National Trust, Nassau, The Bahamas

DAVID KNowles Bahamas National Trust, Abaco National Park, Abaco, The Bahamas

JAVIER FrANCISCO-ORTEGa $\dagger$ (Corresponding author) Department of Biological Sciences, Florida International University, Miami, USA. E-mail ortegaj@fiu.edu

*Also at: Department of Biological Sciences, Florida International University, Miami, USA

$\dagger$ Also at: Fairchild Tropical Botanic Garden, Coral Gables, Miami, USA

Received 19 October 2011. Revision requested 11 January 2012.

Accepted 6 February 2012.

\section{Introduction}

There are c. 331 species of cycads in 10 genera (Osborne et al., 2012) and they are often referred to as living fossils because they first appeared in the Triassic (Norstog \& Nicholls, 1997). These gymnosperms are rapidly disappearing because of habitat loss and their popularity in the ornamental plant trade, which has led to drastic declines in population size (Osborne, 1995). Most cycad species are currently on the IUCN Red List (IUCN, 2011) and their trade is regulated by CITES (CITES, 2011). All cycads are dioecious and their pollination and dispersal biology constrain both gene flow and population recruitment to relatively small geographical areas (Norstog \& Nicholls, 1997).

There are two cycad genera in the Caribbean island biodiversity hotspot: Microcycas and Zamia. The former is a monotypic Critically Endangered genus restricted to Cuba (Pinares et al., 2009). Zamia (c. 71 species) has a wider distribution from Bolivia to Central America, Mexico, Florida and the West Indies. The Caribbean island species form a monophyletic group with c. nine recognized species, known as the Z. pumila complex (Stevenson, 1987). Three of these taxa occur in the Bahamas archipelago: Z. angustifolia (also present in Cuba), Z. integrifolia (also occurring in Cuba and Florida), and Z. lucayana (Fig. 1). The latter (Plate 1 ) is endemic to Long Island. $Z$. tenuis is another species reported for the Bahamas but it is only known from a single specimen collected in the early 19th century from a plant cultivated at Berlin Botanical Garden. Z. tenuis was formerly considered a synonym of $Z$. angustifolia by Britton \& Millspaugh (1920) and is currently treated as a synonym of $Z$. integrifolia (Osborne et al., 2012).

The Commonwealth of the Bahamas consists of 22 inhabited islands, c. 700 cays and nearly 2,400 small islets (Albury, 1975). This archipelago has a fast growing population and a strong tourism industry, which represent challenges to the protection of its unique environment (Anonymous, 2002). It is estimated that this archipelago has 110 endemic seed plant species (c. $9 \%$ of the native flora; Acevedo-Rodríguez \& Strong, 2012). As far as we are aware no Bahamian endemic species has been the subject of a comprehensive study focusing on (1) its conservation status, (2) challenges for management, (3) conservation genetics, (4) ex situ conservation, and (5) current threats. Such studies are particularly relevant to the Bahamas as this archipelago 

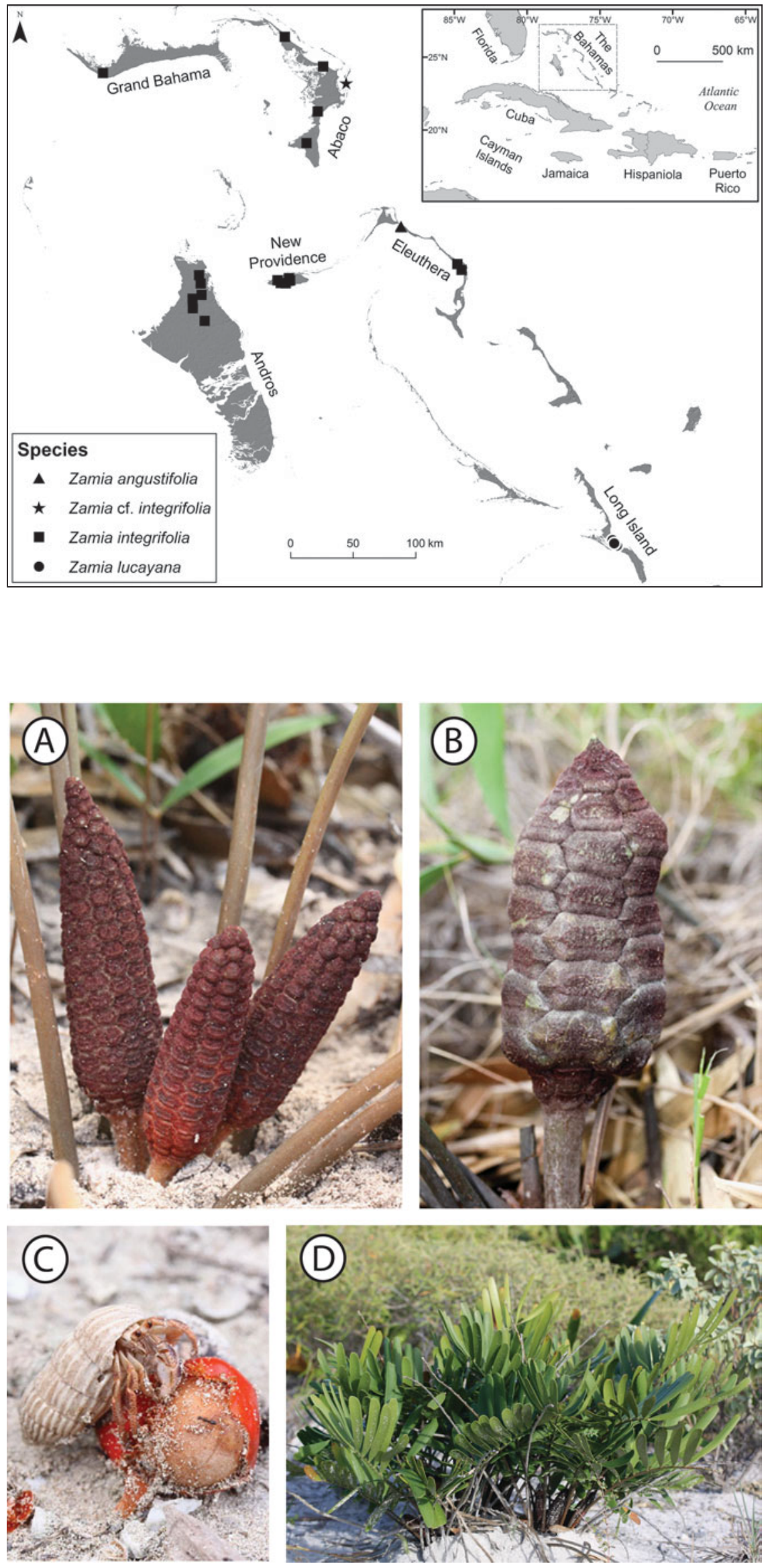

FIG. 1 Distribution of the three species of Zamia in the Bahamas Islands. Each point represents a population included in our field studies. Population symbols overlap on Andros, Eleuthera, and New Providence. Plants from Tilloo Cay, Abaco, were identified as Zamia cf. integrifolia for this study. See Table 1 for number of populations and species studied on each island. The inset indicates the location of the Bahamas in the Caribbean.
Plate 1 Zamia lucayana: (A) male cones, (B) female cone, (C) hermit crab Coenobita clypeatus feeding on the fleshy seed coat, (D) adult male individual. 
is part of the Caribbean island biodiversity hotspot (Maunder et al., 2008). Here, we formulate conservation assessments of Bahamian Zamia species, with special emphasis on the Long Island endemic Z. lucayana.

\section{Methods}

\section{Collecting sites}

Prior to our field studies we compiled a list of historical sites for the target species as recorded by collections deposited in seven herbaria (BW, BNH, C, FTG, GH, MO, NY; acronyms follow Thiers, 2011). In addition, we consulted floristic and taxonomic treatments that include information concerning the distribution of the genus in the Bahamas (Britton, 1907, 1909; Hill, 1974; Eckenwalder, 1980; Correll \& Correll, 1982), and gathered provenance information from living collections at Montgomery Botanical Center and Fairchild Tropical Botanic Garden. Between December 2009 and July 2011 we conducted field studies on the five islands where the three species occur (Table 1, Fig. 1). Each island has only one species, except Eleuthera, where $Z$. angustifolia and $Z$. integrifolia co-occur, although their distribution ranges do not overlap (Fig. 1). We visited a total of 24 populations (Fig. 1, Table 1) and we also explored areas where the species were not previously reported.

\section{Conservation assessments and demographic surveys}

For each site and island we gathered information pertinent to the cycads' conservation status and threats. Field studies were more exhaustive for Z. lucayana, for which we estimated total distribution area, number of adult and juvenile plants, and the approximate ratio of males to females. Juveniles are readily identified by their overall smaller size, absence of remains of reproductive structures, lower number of leaves (usually $<4$ ) on the stem, and lower number (usually $<5$ pairs) of leaflets on the leaves. These demographic data were obtained through a census of $10 \times 10 \mathrm{~m}$ plots that covered c. $25 \%$ of the populations. Locations of individual plants occurring at the edges of the populations were determined with a global positioning system; these points were imported to ArcMap v. 10 (ESRI, Redlands, USA) and used to determine area of occupancy and extent of occurrence (IUCN, 2011) for the species.

\section{Microsatellite DNA analysis}

We used 15 DNA microsatellites to investigate the genetic structure of $Z$. lucayana. The three known populations of $Z$. lucayana were included (Table 2) and we sampled 33-46 individuals per population. DNA was isolated following the protocols described by Meerow \& Nakamura (2007). Microsatellite loci were developed in two ways.
A modified version of the enrichment/hybridization method of Edwards et al. (1996) was used with genomic DNA of Florida Z. integrifolia (Meerow \& Nakamura, 2007; Meerow et al., 2007, 2012a,b). The second methodological approach involved retrieving of microsatellite loci in the Zamia expressed sequence tag (EST) databases available in GenBank using the Simple-Sequence Repeat Identification Tool in GRAMENE (Ware et al., 2002). Six of the 15 loci (Zam28, Zam33, Zam34, Zam39, Zam40, Zam45) have been previously published (Meerow \& Nakamura, 2007). Protocols for PCR amplification and subsequent visualization of SSR fragments follow Meerow \& Nakamura (2007).

Descriptive statistics (Table 2) were generated with GenAlEx v. 6.41 (Peakall \& Smouse, 2005). Tests for Hardy-Weinberg equilibrium and the $U$ test (Rousset \& Raymond, 1995) for heterozygote excess or deficiency were run with GenePop v. 4.0 using 10,000 Monte Carlo Markov chain iterations (Guo \& Thompson, 1992). Linkage disequilibrium (LD) was tested for each population with ARLEQUIN v. 3.5 (Excoffier et al., 2005) using a likelihoodratio test (Slatkin \& Excoffier, 1996). A Monte Carlo Markov chain method was applied with 100,000 iterations, a burn-in of 10,000 and the significance level set at $\mathrm{P}<0.001$.

Analysis of molecular variance (AMOVA) among populations, and permuted calculation of $F_{\mathrm{ST}}(10,000$ permutations) were generated with GenAlEx. An additional measure of gene diversity, $D_{\text {est }}$ (Jost, 2008), was calculated with SMOGD (Crawford, 2010).

Genetic distance among populations and individuals was calculated with POPULATIONS v. 1.2.31 (Langella, 2010), using $D a$ (Nei et al., 1983). The population distance matrix was used for permuted (10,00o iterations) Mantel (1967) tests for isolation by distance following the methods of Smouse et al. (1986) and Smouse \& Long (1992), as implemented in GenAlEx. These distance coefficients were also used in principal coordinate analysis with GenAlEx. BOTTLENECK 1.2.02 (Cornuet \& Luikart, 1996) was used to test for recent genetic bottlenecks in the populations under both the infinite allele model (Kimura \& Crow, 1964) and the two phase model (Di Rienzo et al., 1994).

The Bayesian clustering programme STRUCTURE v.2.3.3 (Pritchard et al., 2000) was used to estimate the underlying genetic structure among populations. The STRUCTURE analyses were carried out on the University of Oslo Bioportal (Kumar et al., 2009). $K$ values of $1-15$ were simulated across 20 replicate runs of 1,000,000 iterations after a burn-in of 100,000. The $\Delta k$ method of Evanno et al. (2005) as implemented in STRUCTURE HARVESTER (Earl \& vonHoldt, 2012) was used to determine the 'true' value of $K$ across samples. After the likely level of $K$ was estimated, a consensus Q-matrix from the 20 runs was constructed using CLUMPP (Jakobsson \& Rosenberg, 2007) for visualization with DISTRUCT (Rosenberg, 2004). 
TABLE 1 The six islands of the Bahamas archipelago (Fig. 1) on which cycads of the genus Zamia occur, with the species present, and the number of populations studied, seeds collected, and individuals sampled for DNA studies.

\begin{tabular}{|c|c|c|c|c|}
\hline Island & Species & $\begin{array}{l}\text { No. of } \\
\text { populations } \\
\text { studied }\end{array}$ & $\begin{array}{l}\text { No. of seeds collected } \\
\text { (no. of mother plants } \\
\text { sampled for seeds)/no. } \\
\text { of seedlings collected }\end{array}$ & $\begin{array}{l}\text { No. of individuals } \\
\text { sampled for DNA } \\
\text { studies }\end{array}$ \\
\hline Abaco $^{*}$ & Z. integrifolia & 5 & $798(16) / 0$ & 76 \\
\hline Andros & Z. integrifolia & 6 & $497(8) / 0$ & 158 \\
\hline \multirow[t]{2}{*}{ Eleuthera } & Z. angustifolia & 2 & $400(11) / 40$ & 37 \\
\hline & Z. integrifolia & 2 & $236(8) / 18$ & 46 \\
\hline Grand Bahama & Z. integrifolia & 1 & $196(8) / 0$ & 45 \\
\hline Long Island & Z. lucayana & 3 & $910(16) / 0$ & 114 \\
\hline New Providence & Z. integrifolia & 5 & $670(14) / 17$ & 125 \\
\hline Total & & 24 & $3,707(81) / 75$ & 602 \\
\hline
\end{tabular}

${ }^{*}$ Includes the Tilloo Cay site

TABle 2 Main demographic features and descriptive genetic diversity statistics for the three populations of $Z$. lucayana.

\begin{tabular}{lccc}
\hline & Hamilton's & Buckley's & Petty's \\
\hline Population code & ZBLI1 & ZBLI2 & ZBLI3 \\
No. of adults & 400 & 250 & 300 \\
No. of juveniles & 267 & 643 & 828 \\
No. of females & 120 & 53 & 144 \\
No. of males & 160 & 125 & 120 \\
No. of adults without & 120 & 72 & 36 \\
$\quad$ cones (unknown sex) & & & \\
Approximate area of & 0.45 & 0.13 & 0.06 \\
$\quad$ occupancy (km ${ }^{2}$ ) & & & \\
No. of individuals & 46 & 43 & 33 \\
$\quad$ sampled for DNA & & & \\
$\quad$ studies & & & \\
Average no. of alleles per & 5.3 & 4.5 & 4.3 \\
$\quad$ locus & & & \\
No. of private alleles & 15 & 15 & 7 \\
Observed heterozygosity & 0.519 & 0.478 & 0.454 \\
Expected heterozygosity & 0.501 & 0.486 & 0.483 \\
Inbreeding coefficient & 0.040 & 0.090 & 0.053 \\
$\begin{array}{l}\text { Percentage of paired loci } \\
\text { in linkage }\end{array}$ & 5 & 0 & 1 \\
disequilibrium & & & \\
\hline
\end{tabular}

\section{Results}

\section{Distribution patterns}

With few exceptions (Lubber's Quarters Cay off the coast of Abaco and in the vicinity of Eight Mile Rock, Grand Bahama), we found populations of Zamia in the areas recorded on the herbarium specimens and in the relevant literature. In our field surveys beyond the historical distribution ranges we did not find any new localities for the species, with the exception of those located on the cays near Abaco.

$Z$. angustifolia is extremely rare and occurs only on coastal sand dunes of Eleuthera. We found only 150 plants in two sites within a small area of $0.34 \mathrm{~km}^{2}$ near Gregory Town (Fig. 1).

Z. integrifolia is typically found in the understorey of the Bahamian pine forests and occasionally in dry evergreen forests, except on Tilloo Cay and Eleuthera. In these two islands pine forests are not present and the species occurs on limestone bluffs in coastal thicket (Eleuthera) or in sandy coastal scrub (Tilloo Cay). The species is abundant in Abaco, relatively common in northern areas of North Andros and locally abundant in a few areas with unfragmented pine forest on New Providence. However, it is rare on Grand Bahama and Eleuthera (Fig. 1).

Z. lucayana occurs on the eastern coast of Long Island between the settlements of Hamilton's and Buckley's (Fig. 2). The three populations grow exclusively within a narrow strip (c. $6.5 \mathrm{~km}$ by $100 \mathrm{~m}$ wide) of coastal scrub vegetation on sandy soils in association with sea grape Coccoloba uvifera, occupying a total area of c. $1 \mathrm{~km}^{2}$. The combined area of occupancy for the surveyed populations is $0.06 \mathrm{~km}^{2}$ (Table 2). Approximately $80 \%$ of the fertile adult individuals surveyed were male and $20 \%$ female (Table 2). Approximately $27 \%$ of individuals were juvenile plants (Table 2). All female individuals with mature cones had nearly complete seed set, indicating efficient pollination. We observed hermit crabs Coenobita clypeatus feeding on the fleshy seed coats, perhaps accelerating germination and short-range dispersal (Plate 1). We estimated there are c. 980 adult individuals throughout the entire range of this species, with 240-400 plants per population (excluding the two outlier sites; Table 2).

\section{Population genetics of $Z$. lucayana}

The 15 polymorphic microsatellite loci uniquely genotyped all 122 individuals assayed; i.e. there were no identical repeated multi-locus genotypes. The mean number of alleles was $4.3-5.3$ (Table 2 ) but the populations had a relatively 


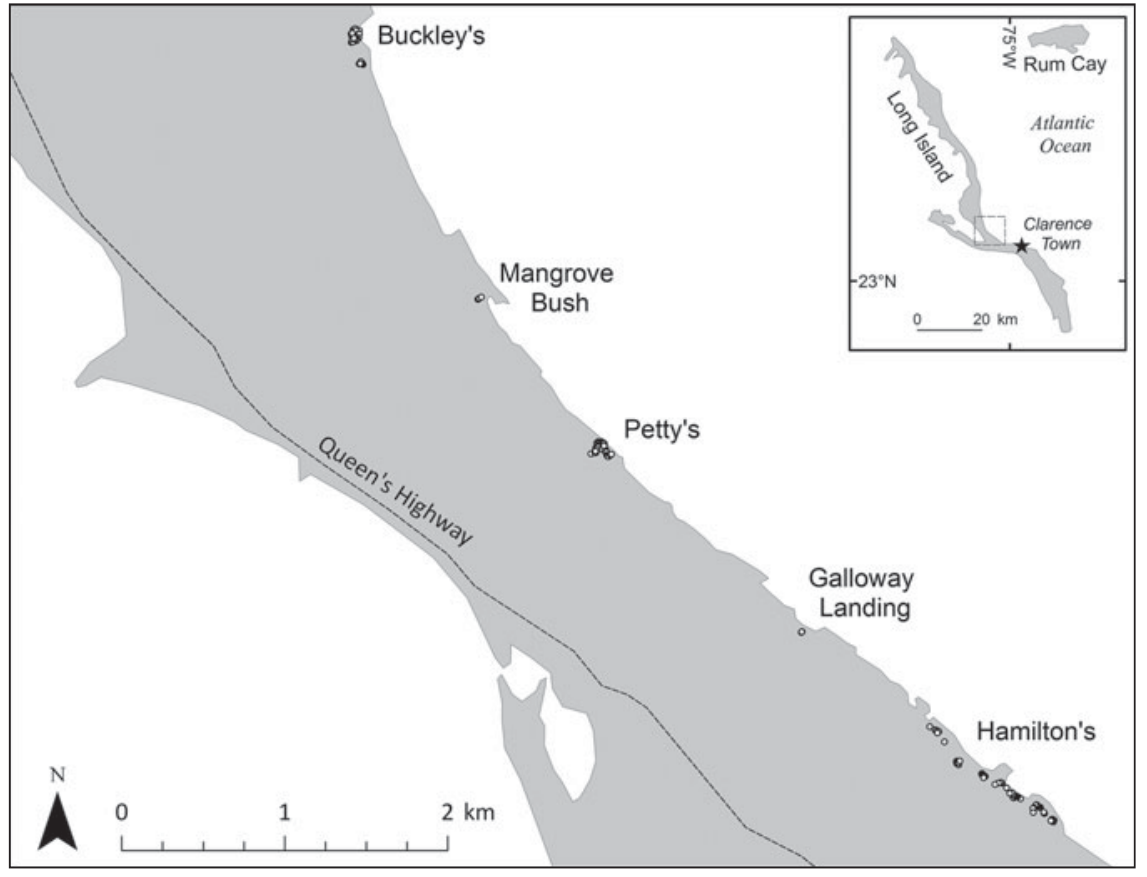

Fig. 2 Distribution of Zamia lucayana on Long Island, showing the three major populations included in the conservation genetic study (Buckley's, ZBLI2; Hamilton's, ZBLI1; Petty's, ZBLI3) and two further localities (Galloway Landing, where 10 adult plants were observed, and Mangrove Bush, where 20 adult plants were observed). Each dot represents a site where individual leaflets were sampled for genetic studies (Table 2). No material was sampled at Galloway Landing or Mangrove Bush.
TABle 3 Pairwise $D_{\text {est }}$ values (above diagonal) and $F_{\mathrm{ST}}$ values (below diagonal) for the three populations of $Z$. lucayana (Table 2).

\begin{tabular}{llll}
\hline & ZBLI1 & ZBLI2 & ZBLI3 \\
\hline ZBLI1 & & 0.051 & 0.045 \\
ZBLI2 & 0.075 & & 0.040 \\
ZBL13 & 0.060 & 0.062 & \\
\hline
\end{tabular}

high number of private alleles, with seven for ZBLI3 and 15 for both ZBLI1 and ZBLI2 (Table 2). All populations are moderately heterozygous (Table 2). All but ZBLI1 are slightly inbred but variation in $F$ was not significant. ZBLI1 also has the highest mean number of alleles per locus. Exact tests found no significant departure from Hardy-Weinberg equilibrium in any populations. Overall, there was 6\% linkage disequilibrium among loci, the majority of which were concentrated in ZBLI2 (5\%). ZBLI1 had no loci in LD; ZBLI3 had two.

Mean $F_{\mathrm{ST}}$ was highly significant $(0.067, \mathrm{P}<0.0001)$ but indicates little differentiation among populations (Table 3). Similarly Jost's $D_{\text {est }}$ estimate of differentiation is low, at 0.04-0.051 (Table 3). The mean number of migrants $(\mathrm{Nm})$ determined by the $F_{\mathrm{ST}}$ method is 3.6 (range 3.07-3.94; Table 4), indicating gene flow among the populations. There is no significant isolation by distance among the populations. Over $90 \%$ of the genetic variation is within populations (Table 5).

The Evanno method of determining the true $K$ identified $K=2$ as optimal across all $Z$. lucayana populations (Fig. 3). ZBL3 is located between ZBLI1 and ZBL2; it shows a closer genetic relationship to ZBLI1 but with some significant admixture from ZBLI2. Principal coordinate
TABLE 4 Estimates of the number of migrants per generation and significance $(\mathrm{P})$ of the analysis of molecular variation (AMOVA) between the three populations of $Z$. lucayana.

\begin{tabular}{lll}
\hline Population comparison & No. of migrants & $\mathrm{P}$ \\
\hline ZBLI1-ZBLI2 & 3.074 & $<0.001$ \\
ZBLI1-ZBLI3 & 3.936 & $<0.001$ \\
ZBLI2-ZBLI3 & 3.778 & $<0.001$ \\
\hline
\end{tabular}

TABLE 5 Analysis of molecular variance for the three populations of $Z$. lucayana. The results indicate that the majority of genetic variation is found within, rather than among, populations.

\begin{tabular}{lcccr}
\hline Source & df & $\begin{array}{c}\text { Sum of } \\
\text { squares }\end{array}$ & $\begin{array}{l}\text { Estimated } \\
\text { variance }\end{array}$ & $\%$ \\
\hline $\begin{array}{l}\text { Among } \\
\text { populations }\end{array}$ & 2 & 51.270 & 0.273 & 7 \\
$\begin{array}{l}\text { Within } \\
\text { populations }\end{array}$ & 239 & 911.739 & 3.815 & 93 \\
Total & 241 & 963.008 & 100 & \\
\hline
\end{tabular}

analysis indicates much the same as the Bayesian clustering (Fig. 4) and ZBLI3 mostly overlaps with ZBLI2. The first two coordinates of this analysis accounted for $43.44 \%$ of the variation.

Across all three Z. lucayana populations there is only weak evidence of genetic bottlenecks. ZBLI1 and ZBLI2 only tested at $\mathrm{P}<0.05$ for the Sign test under the infinite allele model. ZPLI3 tested at $\mathrm{P}<0.05$ for both the Sign and Wilcoxon tests under the infinite allele model. With the two phase model imposed there was no evidence of bottlenecks in any of the populations. 


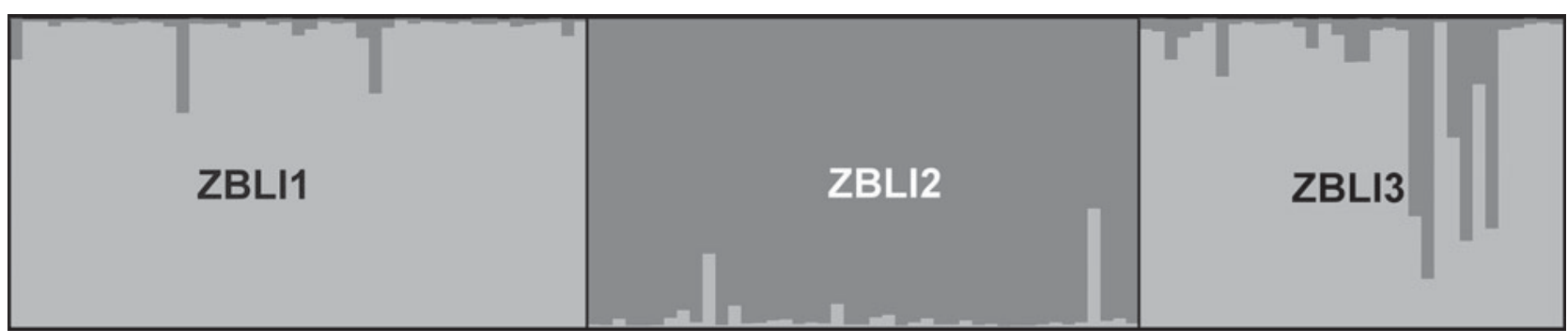

FIG. 3 Graphical representation of genetic structure across three populations of Z. lucayana using Bayesian clustering of microsatellite frequency data. $K=2$ was found to be the optimal partition of genetic variation. The individuals of ZBLI1 and ZBLI3 are predominantly assigned to the same cluster (light grey), whereas ZBLI2 is primarily assigned to the second (dark grey). Admixture between the two clusters is indicated by varying proportions of the opposing colour in individuals of each population. ZBLI3 shows a greater proportion of admixture with ZBLI2 than does ZBLI1.

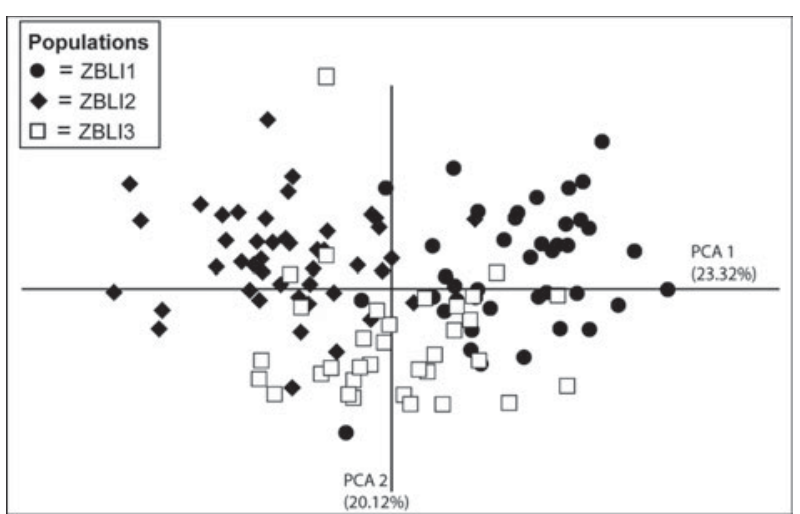

FIG. 4 The first two axes (PCA1, PCA2, with the percentage variation explained by each) of a principal coordinate analysis of DNA microsatellite data for the three main populations of Z. lucayana (Table 2, Fig. 2). Each point represents a single individual.

\section{Discussion}

\section{Distribution patterns and conservation implications}

Z. angustifolia is the species of highest conservation concern because of the small number of adult plants, its limited habitat extent, and the extensive housing development projects occurring in this area. The species also occurs in Cuba, where it is relatively abundant (González Géigel, 2003). However, it is uncertain whether the narrow-leaved morph of Cuba is the same taxon that occurs on Eleuthera. The Bahamian populations are highly threatened and additional studies that include the Cuban populations are needed to determine the conservation status of this species.

Z. lucayana was described by Britton (1907) based on a single individual reported in an unknown locality apparently near Clarence Town (Fig. 2). Later Hill (1974) rediscovered this species, finding a dense population in the vicinity of Hamilton's Settlement (Fig. 2). Our field studies confirmed the existence of this population and we discovered two additional populations near the Settlements of Buckley's and Petty's. We found that human activities have not yet had a major negative effect on the populations of Z. lucayana. The population at Hamilton's Settlement is within an area that has been exploited for sand mining but this activity is localized. All the locations of this species are accessible by road and are on prime ocean-front real estate that has been subdivided for sale, although few houses have been built.

New Providence and Grand Bahama are the two islands where Z. integrifolia is at most risk. As urban development of Nassau expands westwards the remaining habitats of this species will be destroyed; its future on the island is thus uncertain. On Grand Bahama the species occurs near Freeport, at a few sites within an area with intense industrial development.

\section{Conservation genetics}

Critically Endangered species usually have reduced numbers of populations and individuals per population (IUCN, 2011) and the genetic structure of their populations may therefore be severely influenced by genetic drift and inbreeding (Höglund, 2009). This results in a decrease in heterozygosity, with subsequent risk of inbreeding depression, and loss of potential adaptive alleles (Peterson \& McCracken, 2005). Nevertheless, our data show that despite its Critically Endangered status (see below) the populations of $Z$. lucayana are still in Hardy-Weinberg equilibrium and are retaining heterozygosity, and are only moderately inbred and exhibit little differentiation.

Our results indicate that the three populations of $Z$. lucayana on Long Island have been a single panmictic population throughout most of their history. The low levels of genetic differentiation (Table 3) and relatively high migration rate (Table 4) among the three populations indicate that gene flow has been historically high. However, the high number of private alleles (Table 2) indicates that genetic drift is occurring, especially in ZBLI1 and ZBLI2. Given the characteristically local dispersal of both pollen and seeds of Zamia (Norstog \& Nicholls, 1997) our 
expectations are that the populations will continue to fragment further if disturbed, and become more inbred. The genetic data indicate that the three populations of $Z$. lucayana should be considered as a single management unit. The population at Petty's has the highest levels of admixture, and therefore this population would be a good source of material for reintroducing the species to other areas of the island or for ex situ conservation.

Our data contrast with those recently reported for other Critically Endangered plant taxa from the Caribbean islands in which microsatellites have been used to determine genetic structure. Namoff et al. (2011) found strong evidence for genetic drift, inbreeding and moderate gene flow for the Critically Endangered palm Pseudophoenix ekmanii, endemic to the Dominican Republic. Geiger at al. (in press) reported that populations of Ipomoea microdactyla from highly fragmented and disturbed areas of South Florida exhibited significantly lower levels of genetic variation than those from the contiguous and well preserved pine forest on Andros Island.

Walters \& Decker-Walters (1991) used isozyme data to determine levels of genetic variation within the $Z$. pumila complex but found limited genetic variation with these markers. Our research suggests that microsatellites are more useful than isozymes to understand the population genetic structure of this species complex (Meerow \& Nakamura, 2007; Meerow et al., 2007, 2012 a,b). This is supported by our results for Z. lucayana.

Most population genetic studies of cycads have been based on isozymes (reviewed by Pinares et al., 2009), with only three studies focusing on Critically Endangered species (Dioon caputoi, Cabrera-Toledo et al., 2008, 2010; Microcycas calocoma, Pinares et al., 2009). Cycas debaoensis is the only Critically Endangered cycad (IUCN, 2011) for which conservation genetic studies based on microsatellites are available (Yang et al., 2008).

The unusual patterns of genetic diversity detected in Z. lucayana are also exhibited by these three other Critically Endangered species, which also exhibit relatively high levels of heterozygosity. These results appear to provide additional support for the hypothesis (Cabrera-Toledo et al., 2008) that in cycads 'rarity is compatible with high levels of genetic diversity'. Unlike many seed plants, cycads are long lived and allogamous. These life-history characteristics may help reduce inbreeding and genetic drift and subsequent detrimental effects to genetic diversity (Cabrera-Toledo et al., 2008).

\section{Conservation recommendations and conclusions}

Z. lucayana is currently categorized as Endangered on the IUCN Red List (IUCN, 2011). We propose that it should be recategorized as Critically Endangered based on criteria
$\mathrm{B} 1 \mathrm{ab}(\mathrm{i}-\mathrm{v})+2 \mathrm{ab}(\mathrm{i}-\mathrm{v})$. This recommendation has been submitted to the IUCN Cycad Specialist Group. This evaluation is based on the species' highly restricted extent of occurrence $\left(1 \mathrm{~km}^{2}\right)$ and area of occupancy $\left(0.06 \mathrm{~km}^{2}\right)$. In addition, $Z$. lucayana requires a unique habitat that is already under residential development.

$Z$. lucayana is one of three single-island endemic plants on Long Island (Taylor, 1921; Correll \& Correll, 1982). The others are Euphorbia longinsulicola and Matelea correllii. The former has a relatively narrow distribution range (Hill, 1976) and partially co-occurs with $Z$. lucayana. Because of the few endemics restricted to Long Island, the protection of $Z$. lucayana and its habitat is clearly a major conservation priority for this island.

We recommend both ex situ and in situ conservation for $Z$. lucayana. The occurrence of the species on private land could impede establishment of an effective management plan. Long-term conservation will therefore depend on whether the Bahamas National Trust and/or the Ministry of the Environment of the Bahamas can purchase the land where this species occurs. Until the required funds are available we recommend the following actions: (1) limit sand mining, (2) plan residential development on central eastern regions of the island that is compatible with the area where $Z$. lucayana occurs, (3) establish national ex situ conservation collections in the Bahamas, with duplicates in other sites, (4) increase conservation awareness for the species through environmental education programmes, and (5) develop voluntary agreements with landowners to limit development on their property.

During our visit we collected a total of 910 seeds for ex situ conservation from 17 individual plants (Table 1) of $Z$. lucayana. In addition, we collected total of 75 seedlings and 2,797 seeds from 65 plants of Z. angustifolia and $Z$. integrifolia. The location of each plant was determined and sent to the Ministry of the Environment of the Bahamas. The collections were based on the protocols developed at the Montgomery Botanical Center (Walters, 1999; Namoff et al., 2010). In each population we collected seed from five plants and a minimum of 50 seeds per individual. Progeny from each plant is accessioned separately for subsequent ex situ conservation planting. This germplasm has been distributed to the Bahamas National Trust, Fairchild Tropical Botanic Garden, Montgomery Botanical Center, the National Germplasm Repository of USDA-ARS at Miami, the Jardín Botánico Francisco Javier Clavijero (Xalapa, Mexico), and Fairylake Botanical Garden (Shenzhen, China). Among these institutions, the Montgomery Botanical Center maintains one of the most comprehensive living collections of Cycadales worldwide, especially of Zamia (Calonje et al., 2009). The seeds we collected had an $85 \%$ germination rate, suggesting that an ex situ conservation programme will be feasible. 


\section{Acknowledgements}

This study was supported by the Mohamed Bin Zayed Species Conservation Fund (project number 0925331) to JFO, MC, AM, and Tamica Rahming (Bahamas National Trust). Matching funds were provided by Montgomery Botanical Center. This project was also supported by the National Science Foundation (award number 1050340) and by the Christiane Tyson Research Fellowship. We thank C. Adair, R. Adams, C. Calonje, S. Gilmer and L. Johnson for their technical assistance. Ethan Freid provided information pertinent to Long Island endemics. We thank the Ministry of the Environment of the Bahamas for Research and Collection Permits and the Bahamas Department of Agriculture for CITES, export and phytosanitary permits. This is contribution 218 of the Tropical Biology Programme of Florida International University.

\section{References}

Acevedo-Rodríguez, P. \& Strong, M.T. (2012) Catalogue of seed plants of the West Indies. Smithsonian Contributions to Botany, 98, 1-1192.

Alb URy, P. (1975) The Story of the Bahamas. St. Martin's Press, New York, USA.

Anonymous (2002) Bahamas Environmental Handbook. Bahamas Environment, Science and Technology Commission, Nassau, The Bahamas.

BRitTon, N.L. (1907) Report on the continuation of the botanical exploration of the Bahama Islands. Journal of the New York Botanical Garden, 8, 71-81.

Britton, N.L. (1909) Contributions to the flora of the Bahamas Islands IV. Bulletin of the New York Botanical Garden, 5, 311-318.

Britton, N.L. \& Millspaugh, C.F. (1920) The Bahama Flora. Published by the authors, New York, USA.

Cabrera-Toledo, D., González-Astorga, J., NicolaldeMorejón, F., Vergara-Silva, F. \& Vovides, A. (2010) Allozyme diversity levels in two congeneric Dioon spp. (Zamiaceae, Cycadales) with contrasting rarities. Plant Systematics and Evolution, 290, 115-125.

Cabrera-Toledo, D., González-Astorga, J. \& Vovides, A. (2008) Heterozygote excess in ancient populations of the critically endangered Dioon caputoi (Zamiaceae, Cycadales) from Central Mexico. Botanical Journal of the Linnean Society, 158, 436-447.

Calonje, M., Husby, C. \& Griffith, P. (2009) The cycad collection at Montgomery Botanical Center. Public Garden, 24, 25-27.

CITES (2011) The CITES Appendices. CITES Secretariat, Geneva, Switzerland. Http://www.cites.org/eng/app/index.php [accessed 25 September 2011].

Cornuet, J. \& Luikart, G. (1996) Description and power analysis of two tests for detecting recent population bottlenecks from allele frequency data. Genetics, 144, 2001-2014.

Correll, D.S. \& Correll, H.B. (1982) Flora of the Bahama Archipelago. A.R. Gantner Verlag K.-G., Vaduz, Liechtenstein.

CraWford, N.G. (2010) SMOGD: software for the measurement of genetic diversity. Molecular Ecology Resources, 10, 556-557. Http:// www.ngcrawford.com/django/jost/ [accessed 17 January 2012].

Di Rienzo, A., Peterson, A.C., Garza, J.C., Valdes, A.M., Slatkin, M. \& Freimer, N.B. (1994) Mutational processes of simple-sequence repeat loci in human-populations.
Proceedings of the National Academy of Sciences of the USA, 91, 3166-3170.

EARL, D.A. \& vonHoldt, B.M. (2012) STRUCTURE HARVESTER: a website and program for visualizing STRUCTURE output and implementing the Evanno method. Conservation Genetics Resources, 4, 359-361. Http://tayloro.biology.ucla.edu/ structureHarvester/ [accessed 17 January 2012].

Eckenwalder, J. (1980) Taxonomy of the West Indian cycads. Journal of the Arnold Arboretum, 61, 701-702.

Edwards, K.J., Barker, J.H.A., Daly, A., Jones, C.J. \& Karp, A. (1996) Microsatellite libraries enriched for several microsatellite sequences in plants. BioTechniques, 20, 758-760.

Evanno, G, Regnaut, S \& Goudet, J. (2005) Detecting the number of cluster of individuals using the software STRUCTURE: a simulation study. Molecular Ecology, 14, 2611-2620.

Excoffier, L., Laval, G. \& Schneider, S. (2005) Arlequin ver. 3.o: an integrated software package for population genetics data analysis. Evolutionary Bioinformatics Online, 1, 47-50. Http://cmpg.unibe.ch/ software/arlequin3/ [accessed 17 January 2012].

Geiger, J.H., Meerow, A.W., Lewis, C., Oviedo, R. \& FranciscoOrTE G A, J. (in press) Genetic diversity and conservation of Ipomoea microdactyla (Convolvulaceae): an endemic vine from the Bahamas, Cuba, and southeastern Florida. Plant Species Biology.

González Géigel, L.G. (2003) Zamiaceae. Flora de la República de Cuba, 8, 3-22.

Guo, S.W. \& Thompson, E.A. (1992) Performing the exact test of Hardy-Weinberg proportion for multiple allele. Biometrics, $48,361-372$.

Hill, S.R. (1974) Range extensions and new records for the Bahama flora. Rhodora, 76, 471-477.

Hill, S.R. (1976) A new species of Euphorbia (section Chamaecyse) from the Bahamas. Sida, 6, 313-316.

Höglund, J. (2009) Evolutionary Conservation Genetics. Oxford University Press, Oxford, UK.

IUCN (2011) The IUCN Red List of Threatened Species v. 2011.2. Http:// www.iucnredlist.org/ [accessed 17 January 2012].

Jakobsson, M. \& Rosenberg, N.A. (2007) CLUMPP: a cluster matching and permutation program for dealing with label switching and multimodality in analysis of population structure.

Bioinformatics, 23, 1801-1806. Http://www.stanford.edu/group/ rosenberglab/clumpp.html [accessed 17 January 2012].

Jost, L. (2008) Gst and its relatives do not measure differentiation. Molecular Ecology, 17, 4015-4026.

Kimura, M. \& Crow, J. (1964) The number of alleles that can be maintained in a finite population. Genetics, 49, 725-738.

Kumar, S., Skjæveland, Å., Orr, R.J.S., Enger, P., Ruden, T., Mevik, B.-H. et al. (2009) AIR: a batch-oriented web program package for construction of supermatrices ready for phylogenomic analyses. BMC Bioinformatics 2009, 10, 357. Http://www.bioportal. uio.no/ [accessed 17 January 2012].

Langella, O. (2010) Populations 1.2.31. Http://bioinformatics.org/ $\sim$ tryphon/populations/ [accessed 17 January 2012].

Mantel, N. (1967) The detection of disease clustering and a generalized regression approach. Cancer Research, 27, 209-220.

Maunder, M., Leiva, A., Santiago-Valentín, E., Stevenson, D.W., Acevedo-Rodríguez, P., Meerow, A.W. et al. (2008) Plant conservation in the Caribbean Island biodiversity hotspot. Botanical Review, 74, 197-207.

Meerow, A.W., Francisco-Ortega, J., Ayala-Silva, T., Stevenson, D.W. \& Nakamura, K. (2012a) Population genetics of Zamia in Puerto Rico, a study with ten SSR loci. Memoirs of New York Botanical Garden, 106, 204-223.

Meerow, A.W., Francisco-Ortega, J., Calonje, M., Griffith, M.P., Ayala-Silva, T., Stevenson, D.W. 
\& Nakamura, K. (2012b) Zamia (Cycadales: Zamiaceae) on Puerto Rico: asymmetric genetic differentiation and the hypothesis of multiple introductions. American Journal of Botany, 99, 1828-1839.

Meerow, A.W. \& Nakamura, K. (2007) Ten microsatellite loci from Zamia integrifolia (Zamiaceae). Molecular Ecology Notes, 7, 824-826.

Meerow, A.W., Stevenson, D.W., Moynihan, J. \& FranciscoORTEGA, J. (2007) Unlocking the coontie conundrum: the potential of microsatellite DNA studies in the Caribbean Zamia pumila complex (Zamiaceae). Memoirs of New York Botanical Garden, $98,484-518$.

Namoff, S., Husby, C.E., Francisco-Ortega, J., Noblick, L.R., Lewis, C.E. \& Griffith, M.P. (2010) How well does a botanical garden collection of a rare palm capture the genetic variation in a wild population? Biological Conservation, 143, 1110-1117.

Namoff, S., Veloz, A., Jiménez, F., Rodríguez-Peña, R.A., Peguero, B., Lewis, C. et al. (2011) Sweet drinks are made of this: conservation genetics of an endemic palm species from the Dominican Republic. Journal of Heredity, 102, 1-10.

Nei, M., Tajima, F. \& Yateno, Y. (1983) Accuracy of estimated phylogenetic trees from molecular data. II. Gene frequency data. Journal of Molecular Evolution, 19, 150-173.

Norstog, K.J. \& Nicholls, T.J. (1997) The Biology of the Cycads. Cornell University Press, Ithaca, USA.

Osborne, R. (1995) The world cycad census and a proposed revision of the threatened species status for cycad taxa. Biological Conservation, 71, 1-12.

Osborne, R., Calonje, M., Hill, K.D., Stanberg, L. \& Stevenson, D.W. (2012) The world list of Cycads/La lista mundial de cícadas. Memoirs of the New York Botanical Garden, 106, 480-510.

Peakall, R. \& Smouse, P. (2005) GenAlEx 6: genetic analysis in Excel. Population genetic software for teaching and research. Molecular Ecology Notes, 6, 288-295. Http://biology.anu.edu.au/GenAlEx/ Welcome.html [accessed 17 January 2012].

Peterson, P.M. \& McCracken, C.L. (2005) Genetic consequences of reduced diversity: heterozygosity loss, inbreeding depression, and effective population size. In Plant Conservation. A Natural History Approach (eds G.A. Krupnick \& W.J. Kress), pp. 194-205. The University of Chicago Press, Chicago, USA.

Pinares, A., González-Astorga, J., Vovides, A.P., Lazcano, J \& Vendrame, W.A. (2009) Genetic diversity of the endangered endemic Microcycas calocoma (Miq.) A. DC. (Zamiaceae, Cycadales): implications for conservation. Biochemical Systematics and Ecology, 37, 385-394.

Pritchard, J.K., Stephens, M. \& Donnelly, P. (2000) Inference of population structure using multilocus genotype data. Genetics, 155, 945-959.

Rosenberg, N.A. (2004) DISTRUCT: a program for the graphical display of population structure. Molecular Ecology Notes, 4, 137-138.
Http://www.stanford.edu/group/rosenberglab/distruct.html [accessed 17 January 2012].

Rousset, F. \& Raymond, M. (1995) Testing heterozygote excess and deficiency. Genetics, 140, 1413-1419.

Slatkin, M. \& Excoffier, L. (1996) Testing for linkage disequilibrium in genotypic data using the expectationmaximization algorithm. Heredity, 76, 377-383.

Smouse, P.E. \& LonG, J.C. (1992) Matrix correlation analysis in anthropology and genetics. Yearbook of Physical Anthropology, $35,187-213$.

Smouse, P.E., Long, J.C. \& Sokal, R.R. (1986) Multiple regression and correlation extensions of the Mantel test of matrix correspondence. Systematic Zoology, 35, 627-632.

Stevenson, D. (1987) Comments on character distribution, taxonomy, and nomenclature with respect to the genus Zamia L. in the West Indies and Mexico. Encephalartos, 9, 3-7.

TAYLOR, N. (1921) Endemism in the Bahama flora. Contributions from the Brooklyn Botanic Garden, 25, 523-532.

Thiers, B. (2011) Index Herbariorum: A Global Directory of Public Herbaria and Associated Staff. New York Botanical Garden's Virtual Herbarium. Http://sweetgum.nybg.org/ih/ [accessed 1o September 2011].

Walters, T.W. (1999) Off-site cycad preservation: II. How to develop off-site collections. Cycad Newsletter, 22, 9-12.

Walters, T.W. \& Decker-Walters, D. (1991) Patterns of allozyme diversity in the West Indian cycad Zamia pumila (Zamiaceae). American Journal of Botany, 78, 436-449.

Ware, D., Jaiswal, P., Ni, J., Pan, X., Chang, K., Clark, K. et al. (2002) Gramene: a resource for comparative grass genomics. Nucleic Acids Research, 30, 103-105. Http://www.gramene.org/db/markers/ ssrtool [accessed 17 January 2012].

YANG, Y., Li, Y., Li, L.-F., GE, X.-J. \& GonG, X. (2008) Isolation and characterization of microsatellite markers for Cycas debaoensis Y.C. Zhing et C.J. Chen (Cycadales). Molecular Ecology Resources, $8,913-915$.

\section{Biographical sketches}

Michael Calonje is a cycad biologist currently studying the phylogenetics and systematics of Zamia. Alan W. MeErow is a research geneticist and systematist specializing in tropical ornamental plants. LINDY KNOWLES is engaged in the management of terrestrial and marine biodiversity at the Bahamas National Trust. DAvid KNowles is the head of Abaco National Park. PATRICK GRIfFith is executive director of Montgomery Botanical Center, working on collections of living plants for conservation. KYOKO NAKAMURA is a biological science technician. Javier Francisco-Ortega has interests in island plant biodiversity. 